\title{
Evaluation of the relationship between diastolic dysfunction and interatrial block
}

\section{Diyastolik disfonksiyon ve interatrial blok arasındaki ilişkinin değerlendirilmesi}

\author{
Zafer Yalım ${ }^{1}$, (I İbrahim Ersoy ${ }^{2}$ \\ ${ }^{1}$ Afyonkarahisar Health Sciences University, Faculty of Medicine, Department of Cardiology, Afyonkarahisar, Turkey \\ ${ }^{2}$ Afyonkarahisar Health Sciences University, Department of Cardiology, Afyonkarahisar Health Science University, Faculty of Medicine, \\ Department of Cardiology, Afyonkarahisar, Turkey
}

Cite this article as/Bu makaleye atıf için: Yalım Z, Ersoy İ. Evaluation of the relationship between diastolic dysfunction and interatrial block. J Health Sci Med 2020; 3(4): 403-408.

\begin{abstract}
Background: The interatrial block (IAB) is a condition that occurs due to the delay of conduction in the right atrium to the left atrium, and can be partial (pIAB) or advanced (aIAB), and also is associated with atrial arrhythmia. Diastolic dysfunction (DD) is an important condition frequently encountered in most healthy middle-aged individuals and plays a role in the development of many cardiovascular diseases. It is noteworthy that frequent paroxysmal atrial fibrillation (PAF) attacks are observed especially in individuals with DD in clinical life, and its relationship with the presence of interatrial block is still unclear in these patients. Our aim in this study was to evaluate the relationship between the presence of DD and the development of interatrial block and PAF.

Material and Method: A total of 146; 92 patients with DD and 54 control (proven by echocardiography) were enrolled in this cross-sectional and prospectively study. The properties of the $\mathrm{P}$ wave were evaluated in leads D2-3 aVF and V1. Echocardiography and electrocardiography results of the two groups were compared.

Results: The mean age of the DD and the control group was $(62.3 \pm 0.74$ and $61.2 \pm 0.61$ years, $\mathrm{p}=0.481)$ respectively. The frequency of IAB was significantly higher in the DD than the control group (37\%-46.7\%-16.3\%, $77.8 \%-18.5 \%-3.7 \%$, and none-pIAB-aIAB, respectively). In the correlation analysis, there was a strong correlation between the presence of DD and IAB ( $\mathrm{r}: 0.439, \mathrm{p}<0.001)$, and the history of PAF and IAB ( $\mathrm{r}$ : $0.458, \mathrm{p}<0.001)$.

Conclusion: In our study, the frequency of IAB was significantly higher in the DD group. We think that it may be beneficial to evaluate P waves more carefully to determine the risky individuals among those who have DD in clinical life.
\end{abstract}

Keywords: Interatrial block, diastolic dysfunction, atrial fibrillation

\section{ÖZ}

Amaç: Interatrial blok (IAB), sağ atriyumda sol atriyuma iletimin gecikmesi nedeniyle ortaya çıan bir durumdur ve kısmi (partial-pIAB) veya gelişmiş (advanced-aIAB) olabilir ve ayrıca atriyal aritmi ile ilişkilidir. Diyastolik disfonksiyon (DD), çoğu sağlıklı orta yaşlı bireyde sık karşılaşılan önemli bir durumdur ve birçok kardiyovasküler hastalığın gelişiminde rol oynar. Özellikle klinik yaşamda DD’li bireylerde sık paroksismal atrial fibrilasyon (PAF) ataklarının gözlenmesi dikkat çekicidir ve bu hastalarda IAB varlığı ile ilişkisi hala belirsizdir. Bu çalışmadaki amacımız DD varlığı ile IAB ve PAF gelişimi arasındaki ilişkiyi değerlendirmektir.

Gereç ve Yöntem: Bu kesitsel ve prospektif çalışmaya DD olan 92 ve 54 kontrol (ekokardiyografi ile kanıtlanmış) olmak üzere toplam 146 kişi dahil edildi. P dalgasının özellikleri, D2-3 aVF ve V1 derivasyonlarında değerlendirildi. İki grubun ekokardiyografi ve elektrokardiyografi sonuçları karşılaştırıldı.

Bulgular: DD ve kontrol grubunun yaş ortalaması sırasıyla ( $62,3 \pm 0.74$ ve $61,2 \pm 0,61$ yıl, $\mathrm{p}=0,481)$ idi. IAB sıklı̆̆ DD’de kontrol grubuna göre anlamlı olarak yüksekti (sırasıyla, \%37-\%46,7-\%16,3, \%77,8-\%18,5-\%3,7, normal-pIAB-aIAB, p<0,001). Korelasyon analizinde DD varlığ ile IAB arasında (r: 0,439, p<0,001) ve PAF ile IAB öyküsü arasında güçlü bir korelasyon olduğu bulundu (r: 0,458, p<0,001).

Sonuçlar: Çalışmamızda DD grubunda IAB sıklığı anlamlı olarak yüksekti. Klinik hayatta DD olanlarda riskli bireyleri belirlemek için P dalgalarını daha dikkatli değerlendirmenin faydalı olabileceğini düşünüyoruz.

Anahtar Kelimeler: İnteratriyal blok, diyastolik disfonksiyon, atriyal fibrilasyon 


\section{INTRODUCTION}

Cardiovascular diseases are common in the general population around the worldwide, affecting the majority of adults older than 60 years, causing most of the deaths in developed countries (1). Diastolic dysfunction (DD) reflects abnormal cardiac relaxation, stiffness or filling, and it plays a key role in the development of heart failure with preserved ejection fraction (HFpEF), atrial fibrillation (AF). Although, preclinical diastolic dysfunction (PDD) is a common finding in older and obese adults. It is a predictor for CVD mortality (2). PDD is a predictor for heart failure and all-cause mortality after controlling for comorbidities $(3,4)$. Also, DD increases LA pressure resulting in atrial dysfunction. Atrial dysfunction, could cause supraventricular arrhythmias and facilitate heart failure (5). Diastolic dysfunction by echocardiography is one of the most important criteria for the diagnosis of HFpEF (6).

The interatrial block (IAB), which was first defined by Bayes de Luna, is a condition that occurs due to the delay of conduction in the right atrium to the LA (7). IAB can be partial (pIAB) or advanced (aIAB) and commonly diagnosed with an electrocardiogram. Because of their association with supraventricular tachyarrhythmia's, electromechanical dysfunction, and embolic stroke, intra and interatrial conduction abnormalities have significant clinical implications (8). Identifying patients with atrial conduction disorders in DD can improve risk classification to guide clinical decisions. Studies have shown that IAB is a predictor for AF development and embolic stroke (9). It has previously been observed that paroxysmal atrial fibrillation (PAF) attacks were more frequent especially individuals with $\mathrm{DD}$ in real life, and relation between IAB and DD is still unclear.

This paper argues that there could be a relation between $\mathrm{DD}$ and $\mathrm{IAB}$, and this relation could determine the presence of PAF.

\section{MATERIAL AND METHOD}

\section{Study Groups}

This study was conducted at the Departments of Cardiology of Afyonkarahisar Health Science University between February 1, 2019 and December 1, 2019. This study was approved by the university /local human research ethics committee and all procedures performed in studies involving human participants were in accordance with the ethical standards of the institutional and/or national research committee and with the 1964 Helsinki declaration and its later amendments or comparable ethical standards.

A total of 146; 92 patients with DD and 54 control (proven by echocardiography) were enrolled in this crosssectional and prospectively study. The study population enrolled randomly among the patients who applied to the cardiology outpatient clinic. All participants have echocardiographic measurements. Laboratory findings and demographic variables of all patients were recorded. The study was approved by the local ethics committee (2019/120) and all participating individuals provided written informed consent. This study was performed according to the Declaration of Helsinki II.

Criteria for exclusion the subjects were as follows: pregnancy, under 18 and over 75 age, heart failure with reduced ejection fraction (HFrEF, $\mathrm{EF}<45 \%$ ), thyroid and other hormonal disorders, cerebrovascular diseases, serious valve disease, cardiac pacemaker, bundle branch block and supraventricular arrhythmia, drugs known to affect atrial conduction, consuming alcohol, and electrolyte disturbance. The following definitions were used; hypertension, blood pressure $\geq 140 / 90 \mathrm{mmHg}$ and/ or use of antihypertensive treatment; dyslipidaemia, total cholesterol levels of $>200 \mathrm{mg} / \mathrm{dl}$ or low density lipoprotein (LDL)-cholesterol levels of $\geq 130 \mathrm{mg} / \mathrm{dl}$ or triglyceride levels of $\geq 150 \mathrm{mg} / \mathrm{dl}$ or HDL cholesterol levels in male $\leq 40$ $\mathrm{mg} / \mathrm{dl}$ in women $\geq 50 \mathrm{mg} / \mathrm{dl}$ and/or using lipid lowering agents; diabetes mellitus, fasting plasma glucose; $\geq 126 \mathrm{mg} /$ $\mathrm{dl}$, two-hour plasma glucose $\geq 200 \mathrm{mg} / \mathrm{dL}$ during an OGTT, random (or "casual") plasma glucose $\geq 200 \mathrm{mg} / \mathrm{dL}$ in the presence of symptoms, and/or glucose lowering treatment. Smokers were defined participants who reported smoking currently and regularly (at least five cigarettes per day). Body mass index weight in kilogram divided by the square of height in meters was obtained.

\section{Echocardiographic Measurements}

Echocardiography was performed with the Phillips EPIQ CVx (Germany, 2008) with a $3.5 \mathrm{MHz}$ transducer probe. A one-lead ECG was recorded continuously during the echocardiographic examination. The thicknesses of the posterior wall and interventricular septum, LA dimensions, LV end-systolic and end-diastolic diameters were obtained using M-mode in parasternal long axis. LVEF was calculated using Simpson's biplane method. The velocities of the mitral $\mathrm{E}$ wave and $\mathrm{A}$ wave, deceleration time of $\mathrm{E}$ wave and E/A ratio were acquired using pulsed Doppler from the apical four-chamber view on the mitral valve. The Valsalva maneuver test was used to separate grade 1-2 DD. Furthermore, velocities and systolic times of the mitral lateral annular were acquired using pulsed Doppler and Tissue Doppler echocardiography from the apical four-chamber view. All echocardiographic procedures were performed by the same operator. Measurements were made in accordance with the recommendations of the American Society of Echocardiography (ASE) and European Association of Cardiovascular Imaging (EACVI) $(10,11)$. According to the ASE and the EACVI guidelines, diastolic filling patterns were categorized as normal, grade I (abnormal relaxation), grade II (pseudo normal), and grade III (restrictive filling). DD classification was made according to the proposed measurements (Table 1). 


\begin{tabular}{|c|c|c|c|c|}
\hline Variables & Normal & $\begin{array}{c}\text { Grade I } \\
\text { (abnormal relaxation) }\end{array}$ & $\begin{array}{c}\text { Grade II } \\
\text { (pseudo normal) }\end{array}$ & $\begin{array}{c}\text { Grade III } \\
\text { (restrictive filling) }\end{array}$ \\
\hline Mitral E/A ratio & $>0,8$ & $\leq 0.8$ & $>0.8-<2$ & $>2$ \\
\hline Average E/e’ratio & $<10$ & $<10$ & $10-14$ & $>14$ \\
\hline LA maximum volume index, $\mathrm{mL} / \mathrm{m}^{2}$ & $<34$ & Normal or increased & $>34$ & $>34$ \\
\hline Decelaration time, msec & $140-240$ & $>240$ & Normal or prolonged & $<140$ \\
\hline İsovolumetric relaxation time, $\mathrm{ms}$ & $>90$ & $>90$ & $<90$ & $<70$ \\
\hline
\end{tabular}

\section{Electrocardiographic Measurements}

A 12-lead ECG (Nihon Kohden Cardiofax S, Tokyo, Japan) was performed according to established standards of American Heart Association Electrocardiography and Arrhythmias Committee (12). One experienced operator blinded to the Echocardiography data analyzed the ECGs. At rest, 12-lead ECG recordings of $1 \mathrm{mV} / \mathrm{cm}$ amplitude and $50 \mathrm{~mm} / \mathrm{sec}$ were obtained. The properties of the $\mathrm{P}$ wave were evaluated in leads D2-3 aVF and V1. And definitions was made according to the following criteria; The $\mathrm{PIAB}$ is characterized by a $\mathrm{P}$ wave duration $\geq 120$ milliseconds (ms) on a 12-lead (ECG). The diagnosis of aIAB is made by a $\mathrm{P}$-wave duration $\geq 120 \mathrm{~ms}$ and a biphasic or $+/-$ morphology of the P-wave in leads II, III, and aVF of the ECG (13).

\section{Statistical Analysis}

Statistical analyses were conducted using IBM SPSS Statistics for Windows, Version 22.0 software (IBM Corp., Armonk, NY, USA). Variables were investigated using visual and analytic methods to determine normal distribution. Descriptive analysis are presented using the mean \pm SD for normally distributed variables, median and interquartile ranges for abnormally distributed variables. A chi-square test was used to compare nominal and categorical variables (such as gender, hypertension, hyperlipidaemia) The mean value of variables with normal distribution was tested with a T-test, and abnormally distributed variables were tested with the non-parametric Mann-Whitney $U$ test. Correlation analysis was applied using Spearman and Pearson tests according to distribution. Multivariate analysis using a logistic regression model was performed to determine presence of $\mathrm{IAB}$ and odds ratios (OR) with a 95\% confidence interval (CI) were calculated. A p-value< 0.05 was considered statistically significant.

\section{RESULTS}

The mean age of the DD and the control group was $62.3 \pm 0.74$ years and $61.2 \pm 0.61$ years, respectively. There were no significant differences between the groups concerning the variables of gender, smoking, hyperlipidaemia, and diabetes mellitus. However, hypertension frequency was higher in DD group than the control. The frequency of IAB was significantly higher in the DD than the control group (37\%-46.7\%-16.3\%, 77.8\%-18.5\%-3.7\%, and none-pIAB-aIAB, respectively). The demographic characteristics of the participants in the study are summarized in Table 2 .

As expected in the analysis of the echocardiographic results of the groups, there were significant differences in the parameters showing diastolic functions. There was no significant difference between the groups in terms of left ventricular diameters, ejection fraction value, and valve functions. All 2D and tissue Doppler echocardiography data of the study groups are presented in Table 3.

In the correlation analysis, there was a strong correlation between the presence of DD and IAB $(r: 0.439, p<0.001)$, and the history of PAF and IAB ( $\mathrm{r}: 0.458, \mathrm{p}<0.001)$. Also, a significant correlation between $\mathrm{DD}$ and IAB with echo parameters were determined as shown in Table 4.

Table 4. Correlation analysis between clinical variables

\begin{tabular}{|c|c|c|c|c|c|}
\hline \multirow{2}{*}{$\begin{array}{l}\text { Diastolic } \\
\text { DF. - } \\
\text { IAB }\end{array}$} & \multicolumn{2}{|c|}{$\begin{array}{c}\text { Spearman's Rho } \\
\text { P value }\end{array}$} & \multirow{2}{*}{$\begin{array}{l}\text { IAB - } \\
\text { PAF }\end{array}$} & \multicolumn{2}{|c|}{$\begin{array}{c}\text { Spearman's Rho } \\
\text { P value }\end{array}$} \\
\hline & R:0.439 & $\mathrm{P}<0.001$ & & R: 0.458 & $\mathrm{P}<0.001$ \\
\hline PAF & R:0.366 & $\mathrm{P}<0.001$ & Age & R: 0.179 & $\mathrm{P}=0.030$ \\
\hline Age & R:0.331 & $\mathrm{P}<0.002$ & IVS & R: 0.166 & $\mathrm{P}=0.045$ \\
\hline LVEDD & R:0.186 & $\mathrm{P}=0.024$ & PW & R: 0.189 & $\mathrm{P}=0.022$ \\
\hline LA & $\mathrm{R}: 0.288$ & $\mathrm{P}<0.001$ & $\mathrm{E} / \mathrm{A}$ & R:- 0.178 & $\mathrm{P}=0.031$ \\
\hline AO & $\mathrm{R}: 0.328$ & $\mathrm{P}<0.001$ & Em & R:- 0.307 & $\mathrm{P}<0.001$ \\
\hline IVS & R:0.338 & $\mathrm{P}<0.001$ & Am & R: 0.260 & $\mathrm{P}=0.002$ \\
\hline PW & R:0.353 & $\mathrm{P}<0.001$ & $\mathrm{Em} / \mathrm{Am}$ & R:-0.350 & $\mathrm{P}<0.001$ \\
\hline E & R:-0.357 & $\mathrm{P}<0.001$ & - & - & - \\
\hline A & R: 0.254 & $\mathrm{P}=0.002$ & - & - & - \\
\hline E/A & R:- -0.415 & $\mathrm{P}<0.001$ & - & - & - \\
\hline $\mathrm{E} / \mathrm{E} \mathbf{m}$ & R: 0.294 & $\mathrm{P}<0.001$ & - & - & - \\
\hline IVRT & R:-0.396 & $\mathrm{P}<0.001$ & - & - & - \\
\hline Em & R:-0.415 & $\mathrm{P}<0.001$ & - & - & - \\
\hline Am & R: 0.294 & $\mathrm{P}<0.001$ & - & - & - \\
\hline Em/Am & R:-0.396 & $\mathrm{P}<0.001$ & - & - & - \\
\hline \multicolumn{6}{|c|}{$\begin{array}{l}\text { p<0.05 statistical significance, A: Late diastolic mitral flow velocities, AO: Aort root, } \\
\text { DD: Diastolic dysfunction, E: Early diastolic mitral flow velocities, IAB: Interatrial } \\
\text { block, IVRT: IIsovolumetric relaxation time, IV: Interventricular septum, LA: Left } \\
\text { atrium, LVEDD: Left ventricular end diastolic diameter, m: Tissue Doppler mitral } \\
\text { flow velocities, PAF: Paroxysmal atrial fibrillation, PW: Posterior wall, Rho: Spearman } \\
\text { correlation coefficient, TDI: Tissue Doppler Imaging }\end{array}$} \\
\hline
\end{tabular}




\begin{tabular}{|c|c|c|c|}
\hline Variables & Control (n:54) & DD (n:92) & P value \\
\hline Gender, Male/Female, n (\%) & $\begin{array}{c}31 / 23 \\
(57.4 \% / 42.6 \%)\end{array}$ & $\begin{array}{c}48 / 44 \\
(52.2 \% / 47.8 \%)\end{array}$ & $0.540^{*}$ \\
\hline Age, year & $61.2 \pm 0.61$ & $62.3 \pm 0.74$ & $0.481 \#$ \\
\hline Diabetes Mellitus, n (\%) & $5(9.3 \%)$ & $17(18.5 \%)$ & $0.133^{\star}$ \\
\hline Hypertension, n (\%) & $13(24.1 \%)$ & $39(42.4 \%)$ & $0.026^{*}$ \\
\hline Hyperlipidemia, n (\%) & $9(16.7 \%)$ & $19(20.7 \%)$ & $0.555^{*}$ \\
\hline Thyroid disorder, n (\%) & $6(11.1 \%)$ & $10(10.9 \%)$ & $0.964^{*}$ \\
\hline CAD, n (\%) & $12(22.2 \%)$ & $18(18.9 \%)$ & $0.701^{\star}$ \\
\hline COPD, n (\%) & $5(9.3 \%)$ & $11(12 \%)$ & $0.614^{*}$ \\
\hline Paroxysmal AF history, n (\%) & $7(13.2 \%)$ & $40(43.5 \%)$ & $0.001^{*}$ \\
\hline $\begin{array}{l}\text { Inter atrial block, n (\%) (None/ Partial/ } \\
\text { Advanced) }\end{array}$ & $\begin{array}{c}42 / 10 / 2 \\
(77.8 \% / 18.5 \% / 3.7 \%)\end{array}$ & $\begin{array}{c}34 / 43 / 15 \\
(37 \% / 46.7 \% / 16.3 \%)\end{array}$ & $0.001^{*}$ \\
\hline \multicolumn{4}{|l|}{ Inter atrial block, Post-hoc analysis } \\
\hline None - Partial & $42(80.8 \%)-10(19.2 \%)$ & $34(44.2 \%)-43(55.8 \%)$ & $<0.001^{\star}$ \\
\hline None-Advanced & $42(95.5 \%)-2(4.5 \%)$ & $34(69.4 \%)-15(30.6 \%)$ & $0.001^{*}$ \\
\hline Partial - Advanced & $10(83.3 \%)-2(16.7 \%)$ & $43(74.1 \%)-15(25.9 \%)$ & $0.499^{*}$ \\
\hline Fasting glucose (mg/dl) & $81(75.7-92.9)$ & $86(81-101)$ & $0.093^{* *}$ \\
\hline Hemoglobin (g/dl) & $13.06 \pm 0.15$ & $13.57 \pm 0.17$ & $0.056 \#$ \\
\hline Creatinine (mg/dl) & $0.89(0.7-0.9)$ & $0.7(0.6-0.9)$ & $0.001^{\star *}$ \\
\hline Total cholesterol (mg/dl) & $154.5(140-169)$ & $165(141-194)$ & $0.090^{* *}$ \\
\hline Triglyceride (mg/dl) & $140(124-164)$ & $154(125-186)$ & $0.167^{\star *}$ \\
\hline LDL- cholesterol (mg/dl) & $91.5(75-115)$ & $97.5(76-125)$ & $0.420^{\star *}$ \\
\hline HDL- cholesterol (mg/dl) & $42(38-49)$ & $41(38-45)$ & $0.163^{\star *}$ \\
\hline $\mathrm{WBC}\left(\mathrm{x} 10^{3} / \mathrm{uL}\right)$ & $7.92(6.07-8.9)$ & $7.35(6.22-9)$ & $0.937^{\star \star}$ \\
\hline Mean platelet volume & $9.85(9.05-11.4)$ & $9.65(8.9-10.5)$ & $0.207^{\star *}$ \\
\hline Neutrophil count $\left(\mathrm{x} 10^{3} / \mathrm{uL}\right)$ & $4(3.4-5.07)$ & $4.29(3.35-5.1)$ & $0.364^{* *}$ \\
\hline Lymphocyte count $\left(\mathrm{x} 10^{3} / \mathrm{uL}\right)$ & $2.42 \pm 0.10$ & $2.30 \pm 0.65$ & $0.285 \#$ \\
\hline Monocyte count $\left(\mathrm{x} 10^{3} / \mathrm{uL}\right)$ & $0.67 \pm 0.25$ & $0.64 \pm 0.20$ & $0.408 \#$ \\
\hline Platelet count $\left(\mathrm{x} 10^{3} / \mathrm{uL}\right)$ & $246.9 \pm 7.97$ & $260 \pm 7.2$ & $0.244 \#$ \\
\hline
\end{tabular}

\begin{tabular}{|c|c|c|c|}
\hline Variables & Control (n:54) & DD (n:92) & $P$ value \\
\hline LVEDD (mm) & $45(43-48)$ & $47.5(45-50)$ & $0.027^{* *}$ \\
\hline $\operatorname{LVESD}(\mathrm{mm})$ & $28(27-30)$ & $29(27-31)$ & $0.268^{\star *}$ \\
\hline LVEF Simpson (\%) & $63(61-65)$ & $63(59-64)$ & $0.067^{\star *}$ \\
\hline IVS (mm) & $9.87 \pm 0.19$ & $11.02 \pm 0.16$ & $<0.001 \#$ \\
\hline $\mathrm{PW}(\mathrm{mm})$ & $9.59 \pm 0.16$ & $10.47 \pm 0.14$ & $<0.001 \#$ \\
\hline LA volume $\left(\mathrm{ml} / \mathrm{m}^{2}\right)$ & $33.5(30-36)$ & $36(34-38)$ & $<0.001^{\star *}$ \\
\hline $\mathrm{AO}(\mathrm{mm})$ & $25.06 \pm 0.4$ & $26.9 \pm 0.3$ & $0.001 \#$ \\
\hline $\mathrm{PAB}, \mathrm{mmHg}$ & $20(15-24)$ & $24(18-28)$ & $0.051^{\star *}$ \\
\hline Diastolic degree, 1-2-3 & - & $60,22,10$ & - \\
\hline Mitral E, $\mathrm{cm} / \mathrm{sn}$ & $110(91.5-124)$ & $70(62.82)$ & $<0.001^{* *}$ \\
\hline Mitral A, $\mathrm{cm} / \mathrm{sn}$ & $69(62-75)$ & $85(72-92)$ & $<0.001^{* *}$ \\
\hline Mitral E/A ratio & $1.56(1.41-1.68)$ & $0.78(0.70-1.11)$ & $<0.001^{\star *}$ \\
\hline Deceleration time (msn) & $152(135-174)$ & $189(156-224)$ & $<0.001^{* *}$ \\
\hline $\mathrm{E} \mathrm{m}, \mathrm{cm} / \mathrm{sn}$ & $11.9 \pm 0.2$ & $7.46 \pm 0.17$ & $<0.001 \#$ \\
\hline $\mathrm{A} \mathrm{m}, \mathrm{cm} / \mathrm{sn}$ & $7.42 \pm 0.19$ & $11.3 \pm 0.28$ & $<0.001 \#$ \\
\hline $\mathrm{S} \mathrm{m}, \mathrm{cm} / \mathrm{sn}$ & $8.92 \pm 0.49$ & $11.2 \pm 0.29$ & $<0.001 \#$ \\
\hline TDI E/A ratio & $1.57(1.42-1.83)$ & $0.66(0.57-0.77)$ & $<0.001^{\star *}$ \\
\hline IVRT, m/sn & $76.92 \pm 1.07$ & $69.79 \pm 1.41$ & $0.001 \#$ \\
\hline Mitral E/Em ratio & $9.4(7.7-10.6)$ & $9.3(8-12)$ & $0.196^{* *}$ \\
\hline MR degree, $n(0-1-2-3-4)$ & $19-31-3-1-0$ & $22-56-12-2-0$ & $0.380^{*}$ \\
\hline TR degree, n (0-1-2-3-4) & $16-31-7-0-0$ & $26-61-4-1-0$ & $0.222^{*}$ \\
\hline AR degree, $n(0-1-2-3-4)$ & $49-5-0-0-0$ & $77-15-0-0-0$ & $0.232^{*}$ \\
\hline PR degree, $n(0-1-2-3-4)$ & $50-4-0-0-0$ & $86-6-0-0-0$ & $0.832^{*}$ \\
\hline
\end{tabular}


In logistic regression analysis; $\mathrm{DD}$ [Odds ratio $(\mathrm{OR})=1.338$, confidence interval (CI) \%95 (0.364-2.312); $\mathrm{p}=0.007]$, PAF [OR: $2.48 \% 95$, CI (1.32-3.63); $\mathrm{p}<0.001$ ] were found to be independent predictors for IAB presence. No significant results were observed in other parameters in regression analysis.

\section{DISCUSSION}

Atrial conduction irregularity is common outcomes of a variety of cardiovascular conditions. In the majority, they are readily identified by non-invasive electrocardiography as an increased $\mathrm{P}$ wave duration as well as characteristic morphologic features. In recent studies have shown that $\mathrm{IAB}$ is associated with many different cardiovascular conditions $(14,15)$. Also, aIAB was found to predict allcause mortality after ischemic stroke (16). DD has seen frequently in daily clinic routine, and there are very few studies in the literature evaluating its relationship with IAB. The main finding of our study was that the frequency of IAB increased in the presence of DD significantly, and there was a strong correlation between IAB and DD. We have also found that $\mathrm{DD}$ was an independent determinant for the development of IAB. In the evaluation of these patients, we think that more attention should be paid to the presence of IAB in their ECG. As we know from previous studies, IAB is a predictor of atrial arrhythmias, particularly AF (17). Given that IAB is associated with increased arrhythmic and embolic events, early recognition of $\mathrm{IAB}$ can help reduce $\mathrm{CV}$ events that may occur in these patients.

Advanced IAB has an estimated prevalence was 0.1$0.5 \%$ in the population, with an incidence of 2.27 per 1000 person-years (15). The frequency of pIAB is much higher. In the large ECG studies reported prevalences of pIAB between $20 \%-47 \%$ of individuals on the different population with sinus rhythm $(18,19)$. Although the incidence of IAB is high, its diagnosis is skipped frequently. However, it was shown in studies that this situation led to important results. In the study of Kaykha et al. (20), approximately 40.000 people were evaluated and found that $\mathrm{IAB}$ were strong predictors of $\mathrm{CV}$ death. In another study, which 7.500 people were evaluated and the followup period was 8.6 years, it was found that $\mathrm{P}$ wave duration was associated with both CV mortality and all-cause death, after adjustment for cardiovascular risk factors (21). Considering this data, the increased frequency of $\mathrm{IAB}$ in individuals with $\mathrm{DD}$ indicates that these patients can cause significant clinical events. In another study that evaluates 11.956 individuals, hypertension and overweight/obesity were the main risk factors for DD, and significantly associated with IAB (22). In our study, the frequency of IAB was significantly higher in the $\mathrm{DD}$ group. We think that it may be beneficial to evaluate $\mathrm{P}$ waves more carefully to determine the risky individuals among those who have DD in clinical life.

As is known, DD is an independent predictor for $\mathrm{AF}$ development. It is known that LA dilatation, fibrosis, and remodelling, especially in these patients, lead to this condition (23). In the echo-Doppler investigation of Goyal and Spodick, was found that IAB was associated with a sluggish, poorly contractile LA and that the degree of dysfunction was related to the degree of conduction delay between the RA and LA (24). In a study investigating LA strain and strain rate using speckle tracking echocardiography, reported that IAB correlates directly with LA structural remodelling and a decrease in LA strain patterns (25). Several studies have implicated IAB in the development of new-onset AF, whereas others have reported no significant associations (26). In previous studies were found that IAB diagnosed from a 12-lead electrocardiogram is associated with a high incidence of subsequent AF (27). Also, IAB associated with an increase of supraventricular tachyarrhythmia's and atrial premature beats (7). It was shown in previous studies that the increase in the frequency of IAB was associated with an increase in the frequency of thromboembolic events other than AF. In our study, the history of PAF was more common in the $\mathrm{DD}$ group. The reason for this relationship may be LA changes due to DD and subsequent IAB. In these patients, early detection of IAB may alert clinicians earlier in terms of AF. We think that the findings of our study may be useful for DD patients, which are common in daily life. Determining the presence of IAB in ECG for the identification of risky patients can be an easy, practical, useful, and inexpensive marker.

\section{Study limitations}

There are some limitations in this study. In our study, the low number of patients, especially the number of control groups, was an important limitation. Other limitations were the evaluation of ECGs and the application of echocardiography. We have not out the high-resolution computer software program for the evaluation of ECG results in this study. Another limitation was the fact that single-center of our study. Also research with a larger number of patients, as well as other contributions, is needed to support our findings.

\section{CONCLUSION}

The aim of the present research was to examine the relevance between DD and IAB. And we found that the frequency of IAB increased significantly in the presence of DD and there was a strong correlation between them. The research has also shown that DD is an independent determinant for the development of IAB. Determining the presence of IAB in ECG for the identification of risky patients can be an easy, practical, useful, and inexpensive marker. 


\section{ETHICAL DECLARATIONS}

Ethics Committee Approval: The study was approved by the Departments of Cardiology of The study was approved by the Afyonkarahisar Health Science University Ethics Committee. University ethics committee (2019/120).

Informed Consent: All patients signed the free and informed consent form.

Referee Evaluation Process: Externally peer-reviewed.

Conflict of Interest Statement: The authors have no conflicts of interest to declare.

Financial Disclosure: The authors declared that this study has received no financial support.

Author Contributions: All of the authors declare that they have all participated in the design, execution, and analysis of the paper, and that they have approved the final version.

\section{REFERENCES}

1. Laslett LJ, Alagona PJ, Clark BA 3rd, et al. The worldwide environment of cardiovascular disease: prevalence, diagnosis, therapy, and policy issues: a report from the American College of Cardiology. J Am Coll Cardiol 2012; 60: S1-49.

2. Wan S-H, Vogel MW, Chen HH. Pre-clinical diastolic dysfunction. J Am Coll Cardiol 2014; 63: 407-16.

3. Kane GC, Karon BL, Mahoney DW, et al. Progression of left ventricular diastolic dysfunction and risk of heart failure. JAMA 2011; 306: 856-63.

4. Redfield MM, Jacobsen SJ, Burnett JCJ, Mahoney DW, Bailey KR, Rodeheffer RJ. Burden of systolic and diastolic ventricular dysfunction in the community: appreciating the scope of the heart failure epidemic. JAMA 2003; 289: 194-202.

5. Yildirir A, Batur MK, Oto A. Hypertension and arrhythmia: blood pressure control and beyond. Europace 2002; 4: 175-82.

6. Paulus WJ, Tschöpe C, Sanderson JE, et al. How to diagnose diastolic heart failure: a consensus statement on the diagnosis of heart failure with normal left ventricular ejection fraction by the Heart Failure and Echocardiography Associations of the European Society of Cardiology. Eur Heart J 2007; 28: 2539-50.

7. Bayes de Luna A, Cladellas $\mathrm{M}$, et al. Interatrial conduction block and retrograde activation of the left atrium and paroxysmal supraventricular tachyarrhythmia. Eur Heart J. 1988; 9: 1112-8.

8. Johner N, Namdar M, Shah DC. Intra- and interatrial conduction abnormalities: hemodynamic and arrhythmic significance. J Interv Card Electrophysiol 2018; 52: 293-302.

9. Lorbar M, Levrault R, Phadke JG, Spodick DH. Interatrial block as a predictor of embolic stroke. Am J Cardiol 2005; 95: 667-8.

10.Sahn DJ, DeMaria A, Kisslo J, Weyman AF. Recommendations regarding quantitation in M-mode echocardiography: results of a survey of echocardiographic measurements. Circulation. 1978; 58: $1072-83$.

11. Nagueh SF, Smiseth OA, Appleton CP, et al. Recommendations for the Evaluation of Left Ventricular Diastolic Function by Echocardiography: An Update from the American Society of Echocardiography and the European Association of Cardiovascular Imaging. J Am Soc Echocardiogr 2016; 29: $277-$ 314.
12. Kligfield P, Gettes LS, Bailey JJ, et al. Recommendations for the standardization and interpretation of the electrocardiogram: part I: The electrocardiogram and its technology: a scientific statement from the American Heart Association Electrocardiography and Arrhythmias Committee, Council on Cl. Circulation 2007; 115: 1306-24.

13. de Luna $\mathrm{AB}$, Platonov $\mathrm{P}$, Cosio FG, et al. Interatrial blocks. A separate entity from left atrial enlargement: a consensus report. J Electrocardiol 2012; 45: 445-51.

14. Ariyarajah V, Asad N, Tandar A, Spodick DH. Interatrial block: pandemic prevalence, significance, and diagnosis. Chest 2005 Aug; 128: 970-5.

15. O'Neal WT, Zhang Z-M, Loehr LR, Chen LY, Alonso A, Soliman EZ. Electrocardiographic advanced interatrial block and atrial fibrillation risk in the general population. Am J Cardiol 2016; 117: 1755-9.

16. Baturova MA, Lindgren A, Shubik Y V, Carlson J, Platonov PG. Interatrial block in prediction of all-cause mortality after firstever ischemic stroke. BMC Cardiovasc Disord 2019; 19: 37.

17. Russo V, Papa AA, Rago A, et al. Interatrial block to predict atrial fibrillation in myotonic dystrophy type 1 . Neuromuscul Disord 2018; 28: 327-33.

18. Nielsen JB, Kühl JT, Pietersen A, et al. P-wave duration and the risk of atrial fibrillation: Results from the Copenhagen ECG Study. Hear Rhythm 2015; 12: 1887-95.

19. Frisella ME, Spodick DH. Confirmation of the prevalence and importance of a 12-lead investigation for diagnosis. Am J Cardiol 2005; 96: 696-7.

20. Kaykha A, Myers J, Desser KB, Laufer N, Froelicher VF. The prognostic importance of isolated $\mathrm{P}$-wave abnormalities. Clin Cardiol 2010; 33: E87-93.

21. Magnani JW, Gorodeski EZ, Johnson VM, et al. P wave duration is associated with cardiovascular and all-cause mortality outcomes: the National Health and Nutrition Examination Survey. Hear Rhythm 2011; 8: 93-100.

22.Sun G, Zhou Y, Ye N, Wu S, Sun Y. Independent associations of blood pressure and body mass index with interatrial block: a cross-sectional study in general Chinese population. BMJ Open 2019; 9: e029463.

23.Eicher J, Laurent G, Mathé A, et al. Atrial dyssynchrony syndrome: an overlooked phenomenon and a potential cause of 'diastolic'heart failure. Eur J Heart Fail 2012; 14: 248-58.

24. Goyal SB, Spodick DH. Electromechanical dysfunction of the left atrium associated with interatrial block. Am Heart J 2001; 142: $823-7$.

25.Lacalzada-Almeida J, Izquierdo-Gómez MM, Belleyo-Belkasem $\mathrm{C}$, et al. Interatrial block and atrial remodeling assessed using speckle tracking echocardiography. BMC Cardiovasc Disord 2018; 18: 38 .

26. Tse G, Wong CW, Gong M, et al. Predictive value of inter-atrial block for new onset or recurrent atrial fibrillation: A systematic review and meta-analysis. Int J Cardiol 2018; 250: 152-6.

27. Agarwal YK, Aronow WS, Levy JA, Spodick DH. Association of interatrial block with development of atrial fibrillation. Am J Cardiol 2003; 91: 882 